\title{
High Temperature Corrosion of Stainless Steel by Fuel Oil Ash*
}

\author{
Yoshimi Ishihara**
}

\begin{abstract}
Summary: Laboratory corrosion tests on stainless steel were carried out to determine the effects of the oil ash deposits taken from the tube surfaces in four boilers. The chemical constituents and the fusing characteristics were also determined.

Conclusions after testing were as followes:

(a) The higher the $\mathrm{I}_{2} \mathrm{O}_{5} / \mathrm{Na}_{2} \mathrm{O}$ ratio of the deposits the greater the corrosion.

(b) Many deposits contained a constituent fusing at about $570^{\circ} \mathrm{C}$.

(c) All of the deposits, which were taken from the superheater tube surfaces, were less corrosive at below $570^{\circ} \mathrm{C}$.
\end{abstract}

\section{Introduction}

High temperature corrosion in boilers has long been a major problem in firing residual fuels. Since 1955 in Japan, in many oil-fired boilers steam temperatures were limited to $540^{\circ} \mathrm{C}$, to prevent serious corrosion by feul oil ash. However, it is necessary to know the effect of residual oil ash deposits on the corrosion if one desires to raise the efficiency of steam generating plant by increasing the steam temperature.

Many researchers reported the effects of $\mathrm{Na}_{2}$ $\mathrm{SO}_{4}$ in $\mathrm{V}_{2} \mathrm{O}_{5}-\mathrm{Na}_{2} \mathrm{SO}_{4}$ mixtures ${ }^{1)-3}$ ), the effects of additives $\left.\left.\left.{ }^{2}, 4\right), 5\right),-9\right)$ and the evaluation of corrosion resisting alloys. ${ }^{10), 11)}$

However, from those reports one could not learn adequate details on the corrosion of superheater tubes in commercial steam power plants.

To obtain this information, laboratory corrosion tests by fuel oil ash deposits were carried out. The present paper describes the examinations of oil ash deposits taken from four boilers and the corrosion tests of SUS 27 stainless steels by the deposits or by the synthetic mixtures simulating such the deposits.

\section{Fuel Oil Ash and $\mathrm{V}_{2} \mathrm{O}_{5}-\mathrm{Na}_{2} \mathrm{SO}_{4}$ Mixtures}

Oil ash deposits were taken from four oil fired boilers prior to cleaning. The boiler specifications are shown in Table 1.

Impurities in fuel oil consumed in those boilers are shown in the table below:

$$
\begin{array}{ll}
\text { Sulfur }(\mathrm{S}) & 2.5-2.7 \% \\
\text { Vanadium }\left(\mathrm{V}_{2} \mathrm{O}_{5}\right) & 40-100 \mathrm{ppm} \\
\text { Sodium }\left(\mathrm{Na}_{2} \mathrm{O}\right) & 20-40 \mathrm{ppm}
\end{array}
$$

The deposits consisted mainly of $\mathrm{V}_{2} \mathrm{O}_{5}, \mathrm{Na}_{2} \mathrm{O}$ and $\mathrm{SO}_{3}$, and the total was about $70-90 \%$, as shown in Table 2. The ratios $\mathrm{V}_{2} \mathrm{O}_{5} / \mathrm{Na}_{2} \mathrm{O}$ and $\mathrm{SO}_{3} /$ $\mathrm{Na}_{2} \mathrm{O}$ in the deposits from the three boilers (A, $\mathrm{B}$ and $\mathrm{C})$ are distributed around the straight lines represented by $\mathrm{Na}_{2} \mathrm{SO}_{4}+\mathrm{xV}_{2} \mathrm{O}_{5}+\mathrm{ySO}_{3}$ (Fig. 1). The $\mathrm{V}_{2} \mathrm{O}_{5} / \mathrm{Na}_{2} \mathrm{O}$ ratio of the deposits was decreased with increasing the tube surface temperatures from which the deposits were taken. But the deposits from $D$ boiler were not distributed on those lines.

$\mathrm{V}_{2} \mathrm{O}_{5}-\mathrm{Na}_{2} \mathrm{SO}_{4}$ mixtures shown below were prepared and used for corrosion tests, and the effect on corrosion was compared with the oil ash deposits.

Table 1. Specification of Power Plant Boilers

\begin{tabular}{l|c|c|c|c}
\hline \multicolumn{1}{c|}{ Name of Power Station } & A & B & C & D \\
\hline Capacity $(\mathrm{t} / \mathrm{h})$ & 435 & 590 & 435 & 260 \\
Pressure $\left(\mathrm{kg} / \mathrm{cm}^{2}\right)$ & 148 & 186 & 149 & 135 \\
Steam Temperature, & 541 & 571 & 541 & 541 \\
$\quad$ Superheater, ${ }^{\circ} \mathrm{C}$ & 541 & 544 & 541 & 541 \\
$\quad$ Reheater, ${ }^{\circ} \mathrm{C}$ & 2.0 & 2.0 & 2.5 & $1 \sim 1.2$ \\
$\mathrm{O}_{2} \%$ in Combustion Gas & '62-6-2 & '63-6-3 & $63-6-14$ & $63-7-10$ \\
Date Sample Deposits & $\mathbf{7}$ months & $\mathbf{5 , 3 0 0 \mathrm { hr }}$ & $\mathbf{2 1 \text { months }}$ & $\mathbf{6 , 1 6 5 \mathrm { hr }}$ \\
$\quad$ Period of Operation &
\end{tabular}

* Received November 20, 1967

** Technical Laboratory, Central Research Institute of
Electric Power Industry (CRIEPI) (1229, Iwato, Komae-machi, Kitatama-gun, Tokyo, Japan). 
Table 2. Chemical Analysis and Melting Points of Oil Ash Deposits in Oil-Fired Boilers

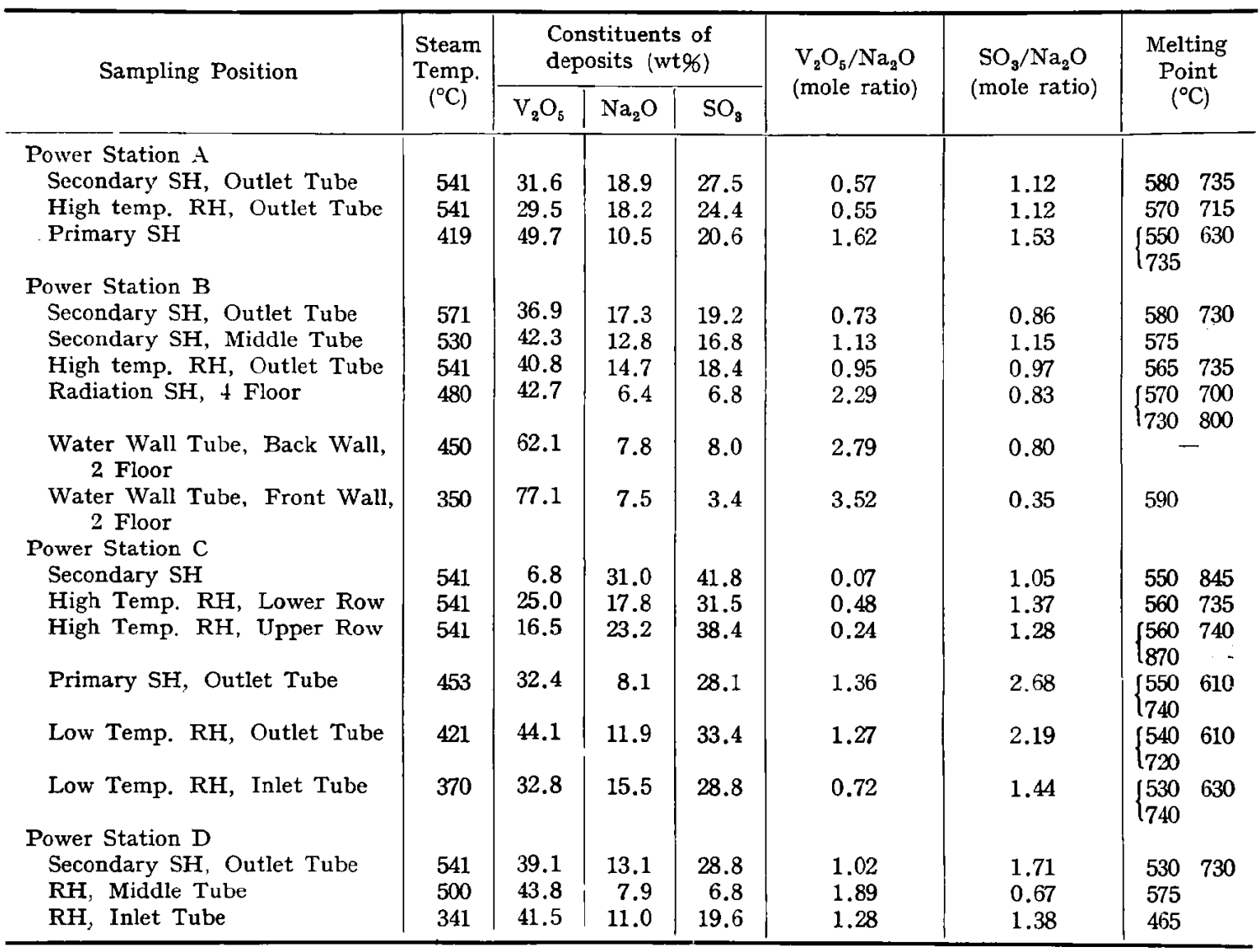

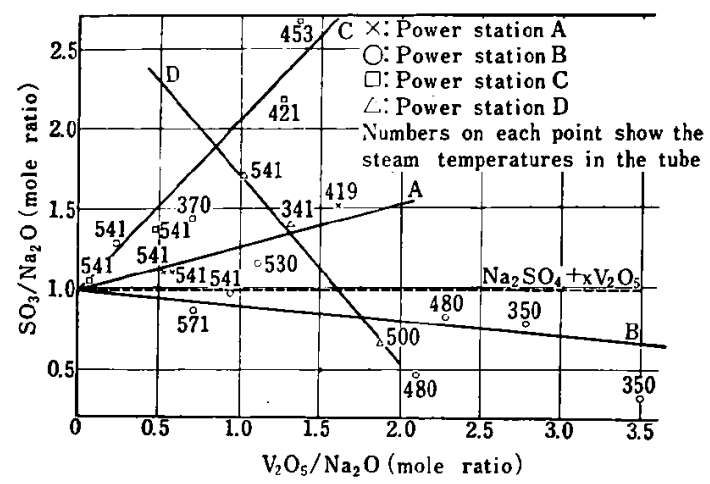

Fig. 1 Distribution of Chemical Compositions in Deposits Taken from Four Boilers

\begin{tabular}{c|c|c}
\hline $\begin{array}{c}\text { Weight Peresent } \\
\text { of } \mathrm{V}_{2} \mathrm{O}_{5}\end{array}$ & $\begin{array}{c}\text { Weight Perecent } \\
\text { of } \mathrm{Na}_{2} \mathrm{SO}_{4}\end{array}$ & $\begin{array}{c}\text { Mole Ratio of } \\
\mathrm{V}_{2} \mathrm{O}_{5} / \mathrm{Na}_{2} \mathrm{O}\end{array}$ \\
\hline 30 & 70 & 0.34 \\
40 & 60 & 0.52 \\
56 & 44 & 1.01 \\
70 & 30 & 1.82 \\
80 & 20 & 3.12 \\
90 & 10 & 7.02 \\
\hline
\end{tabular}

\section{Experimental Procedure}

Corrosion tests were carried out in an electric furnace, and the temperature was held constant during the test period.
Specimens used in those tests were $12.9 \times 12.9 \times$ $0.29 \mathrm{~mm} \quad 18 \mathrm{Cr}-8 \mathrm{Ni}$ stainless steel (SUS 27), polished with sand paper.

Three grams of oil ash deposits or synthetic ash (mixtures of $\mathrm{V}_{2} \mathrm{O}_{5}$ and $\mathrm{Na}_{2} \mathrm{SO}_{4}$ ) were added to $15 \mathrm{ml}$ porcelain crucibles, in which the specimens were immersed. The crucibles containing specimens and ash were put into the electric furance.

After completion of tests, the corroded specimens were immersed in molten caustic soda bath and cathodically descaled. The descaled specimens were washed, dired and re-weighed.

\section{Results and Discussion}

1. Fusion Characteristics of Fuel Oil Ash Deposits

The fusion characteristics of the oil ash deposits were determined by the Leitz high temperature microscope using a similar technique which is used for the determination of the fusibility of coal ash.

The deposits were pressed in $3 \mathrm{~mm} \phi \times 3 \mathrm{~mm}$, and heated in the electric furnace. When the temperature increased to the fusion points of a constituent in the deposit, the sample bulk was 


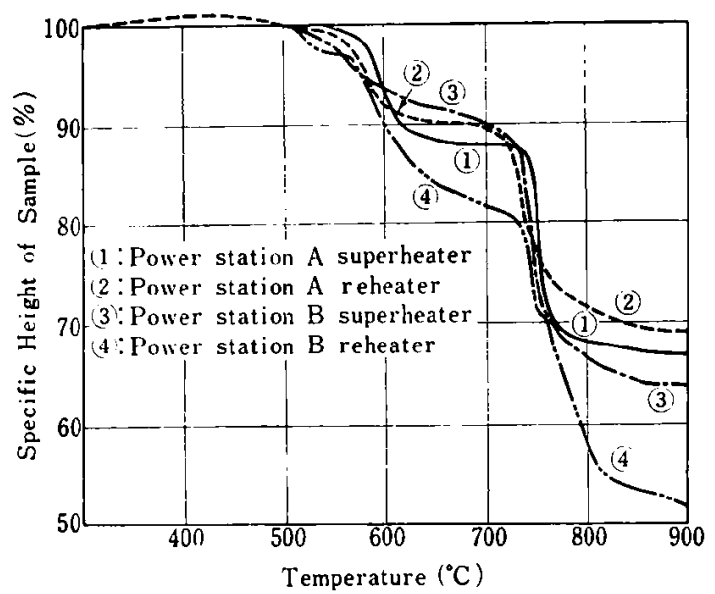

Fig. 2 Fusion Characteristics of the Deposits on High Temperature Superheater and Reheater in Power Stations A and B

shrunk, and the height was decreased as shown in Fig. 2. Four deposits from A and B Power Station have the two constituents, which fuse at the same temperature, $580^{\circ} \mathrm{C}$ and $720-730^{\circ} \mathrm{C}$. Other deposits also have a constituent fusing at below $600^{\circ} \mathrm{C}$. The fusion points of the deposits are shown in Table 2.

Fusion characteristics of $\mathrm{V}_{2} \mathrm{O}_{5}-\mathrm{Na}_{2} \mathrm{SO}_{4}$ mixtures were shown in Fig. 3. The fusion points of $\mathrm{V}_{2} \mathrm{O}_{5}$ $\mathrm{Na}_{2} \mathrm{SO}_{4}$ mixtures, which were given between $610-$ $655^{\circ} \mathrm{C}$, coincided with those obtained by Cunningham. ${ }^{1)}$

Low melting constituents in the oil ash deposits are examined in detail ${ }^{12}$, its compositions are assumed to be vanadyl vanadate $\left(\mathrm{Na}_{2} \mathrm{O}\right.$ $\left.\mathrm{V}_{2} \mathrm{O}_{4} \cdot 5 \mathrm{~V}_{2} \mathrm{O}_{5}, 5 \mathrm{Na}_{2} \mathrm{O} \cdot \mathrm{V}_{2} \mathrm{O}_{4} \cdot 11 \mathrm{~V}_{2} \mathrm{O}_{5}\right)^{13), 14}$

2. Effect of Oil Ash Composition

Corrosion tests used with the oil ash deposits and $\mathrm{V}_{2} \mathrm{O}_{5}-\mathrm{Na}_{2} \mathrm{SO}_{4}$ mixtures were carried out at $600^{\circ} \mathrm{C}$ or $550^{\circ} \mathrm{C}$ for 200 hours.
Table 3. Comparison on Air Corrosion of SUS 27 Stainless Steel with Boiler Deposits at $600^{\circ} \mathrm{C}$ and $550^{\circ} \mathrm{C}$ in 200 Hours

\begin{tabular}{c|c|c}
\hline & \multicolumn{2}{|c}{$\begin{array}{c}\text { Weight Loss } \\
\left(\mathrm{mg} / \mathrm{cm}^{2}\right)\end{array}$} \\
\cline { 2 - 3 } Sampling position & $\mathbf{5 5 0} 0^{\circ} \mathrm{C}$ & $600^{\circ} \mathrm{C}$ \\
\hline Power Station B & & \\
Secondary SH, Outlet Tube & 2.2 & 3.9 \\
Water Wall Tube, back Wall, & 1.0 & 79.1 \\
2 Floor & & \\
Power StationC & & \\
High Temp. RH, Lower Row & 8.6 & 16.8 \\
Primary SH, Outlet Tube & 2.6 & 34.4 \\
Low Temp. RH, Outlet Tube & 2.1 & 20.0 \\
Low Temp. RH, Inlet Tube & 1.3 & 22.9 \\
Power Station D & & \\
Secondary SH, Outlet Tube & 0.3 & 1.0 \\
RH, Middle Tube & 0.8 & 46.2 \\
RH, Inlet Tube & 3.6 & 38.2 \\
\hline
\end{tabular}

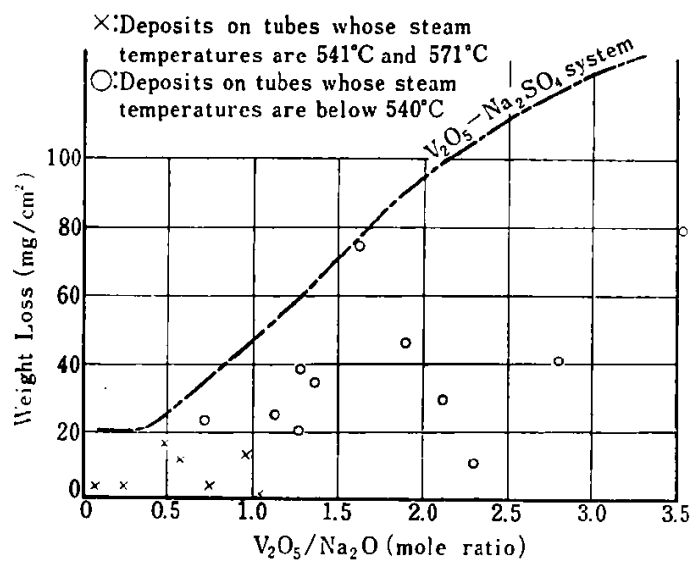

Fig. 4 Effect of $\mathrm{V}_{2} \mathrm{O}_{5} / \mathrm{Na}_{2} \mathrm{O}$ Ratio on Air Corrosion of SUS 27 Stainless Steel with Boiler Deposits at $600^{\circ} \mathrm{C}$ in 200 Hours

These results are shown in Table 3 , and illustrated in Fig. 4. From the figure, it is found that:

(1) Weight losses of specimens exposed at $600^{\circ} \mathrm{C}$

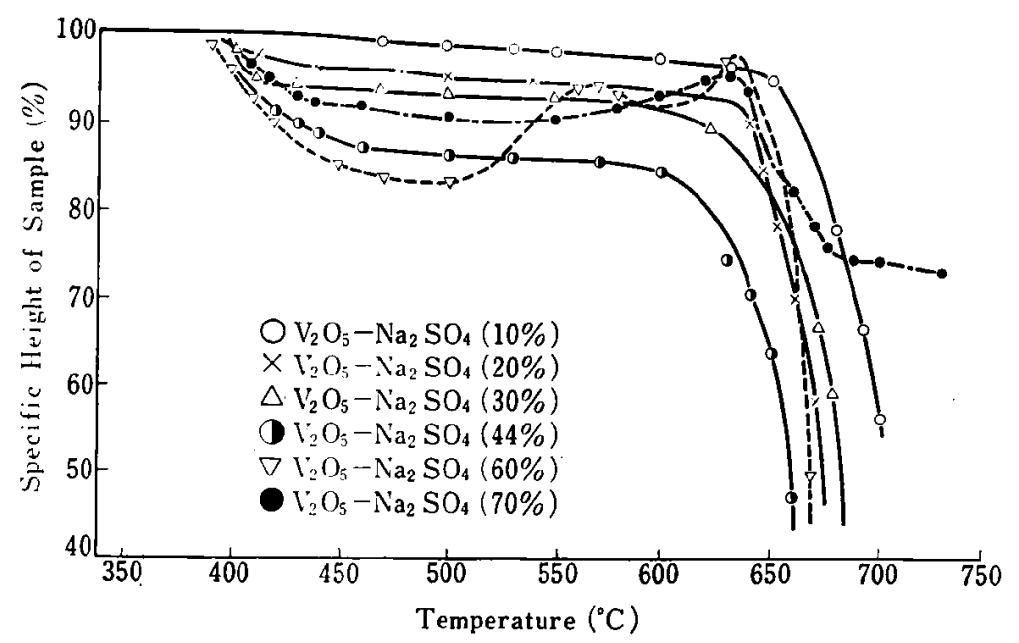

Fig. 3 Fusion Characteristics of $\mathrm{V}_{2} \mathrm{O}_{5}-\mathrm{Na}_{2} \mathrm{SO}_{4}$ Mixtures 
were increased with increasing $\mathrm{V}_{2} \mathrm{O}_{5} / \mathrm{Na}_{2} \mathrm{O}$ ratios of the deposits.

(2) Specimen weight losses by the deposits taken from the highest tube surface temperature zone were below $20 \mathrm{mg} / \mathrm{cm}^{2}$.

(3) Weight losses by oil ash deposits were smaller than those by the $\mathrm{V}_{2} \mathrm{O}_{5}-\mathrm{Na}_{2} \mathrm{SO}_{4}$ mixtures having the same $\mathrm{V}_{2} \mathrm{O}_{5} / \mathrm{Na}_{2} \mathrm{O}$ ratios.

In (2), it is considered that $10-30 \%$ of metal oxides in the deposits, consisting of $\mathrm{Fe}, \mathrm{Ni}, \mathrm{Mg}$, $\mathrm{Ca}, \mathrm{Si}$ etc., decreased the corrosion rate because they react with vanadium oxides and decrease the amount of fusing constituents.

The most corrosive $\mathrm{V}_{2} \mathrm{O}_{5}-\mathrm{Na}_{2} \mathrm{SO}_{4}$ mxitures were those made up to contain $15 \sim 20$ percent $\mathrm{Na}_{2} \mathrm{SO}_{4}$, or those having a mole ratio of 6 to $1{ }^{3}$ ) As the $\mathrm{V}_{3} \mathrm{O}_{5} / \mathrm{Na}_{2} \mathrm{O}$ ratios of the deposits taken from four boilers deceased below 3.5, corrosion weight losses decreased with the decreasing ratio (Fig. 4).

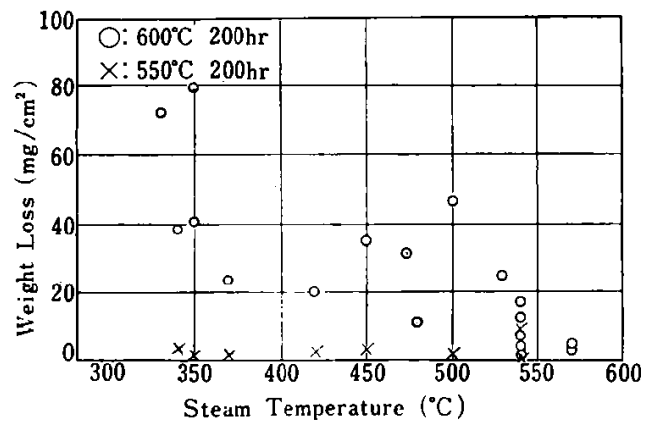

Fig. 5 Effect of Presumed Steam Temperature in the Tube on Air Corrosion of SUS 27 Stainless Steel with Boiler Deposits at $600^{\circ} \mathrm{C}$ and $550^{\circ} \mathrm{C}$ in 200 Hours

\section{Effect of Temperature}

In most of the oil fired boilers, steam temperatures are designed to be $540^{\circ} \mathrm{C}$ or $570^{\circ} \mathrm{C}$.

If the steam temperature is $570^{\circ} \mathrm{C}$, external surface temperature of superheater tube will reach approximately $600^{\circ} \mathrm{C}$.

To examine the effect of temperature on corrosion weight losses by oil ash deposits, experiments were carried out at $600^{\circ} \mathrm{C}$ and $550^{\circ} \mathrm{C}$ for 200 hours. The temperature of $600^{\circ} \mathrm{C}$ corresponds to the highest metal temperatures on superheater tubes, and $550^{\circ} \mathrm{C}$ corresponds to a non-fusing temperature of the deposits.

\section{Effect of the Tube Surface Temperature}

The corrosion weight losses of specimens by the deposits taken from the highest tube surface temperature zones were lower than those taken from the lower temperature zones, as shown in Fig. 5.

\section{Effect of Melting Point}

Corrosion weight losses by the deposits were all below $5 \mathrm{mg} / \mathrm{cm}^{2}$ at $550^{\circ}$ (Fig. 5). Thus, it is apparent that oil ash corrosion did not occur at $550^{\circ} \mathrm{C}$.

\section{Temperatures at which Corrosion Occurred}

To determine the temperature at which oil ash corrosion occures, corrosion tests were carried out at various temperatures between 550 $700^{\circ} \mathrm{C}$.

As shown in Fig. 6, corrosions occurred at above $570-580^{\circ} \mathrm{C}$, and the weight losses increased sharply with increase of the temperatures. In Fig. (c), it is shown that the weight losses at $650^{\circ} \mathrm{C}$ were

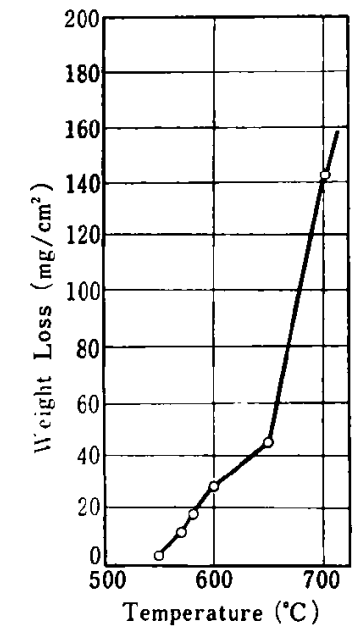

(a) Deposits on the power station B secondary SH outlet tube

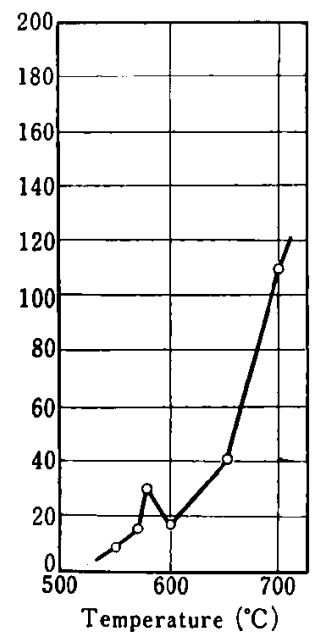

(b) Deposits on the power station $\mathrm{C}$ RH lower row

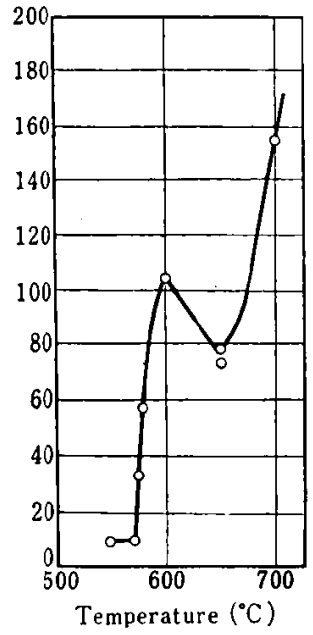

(c) $\mathrm{V}_{2} \mathrm{O}_{5}-\mathrm{Na}_{2} \mathrm{SO}_{4}(30 \%)$ mixture

Fig. 6 Effect of Temperature on Air Corrosion of SUS 27 Stainless Steel with Boiler Deposits in 200 Hours 
lower than at $600^{\circ} \mathrm{C}$. The reasons will be explained below.

\section{Corrosion Rate}

Corrosion weight losses of specimens increased with the length of the test period. To determine its relationship, corrosion tests were carried out at $600^{\circ} \mathrm{C}$ and $700^{\circ} \mathrm{C}$ using both the deposits from the superheater tubes and the $\mathrm{V}_{2} \mathrm{O}_{5}-\mathrm{Na}_{2} \mathrm{SO}_{4}$ mxitures. The results are shown in Fig. 7. Weight losses by the deposits from secondary superheater tube increased sharply at $700^{\circ} \mathrm{C}$, but at $600^{\circ} \mathrm{C}$ the weight losses caused by the same deposits were very small. From the log-log plot, it is considered that the weight losses increased proportionally at $700^{\circ} \mathrm{C}$, however at $600^{\circ} \mathrm{C}$, they increased proportionally with the root test period.

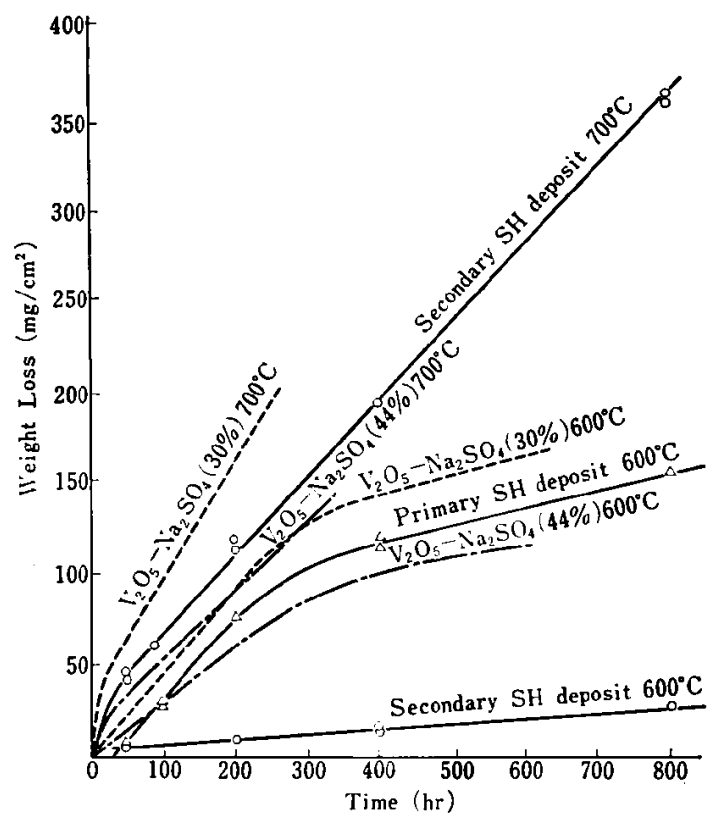

Fig. 7 Corrosion of SUS 27 Stainless Steel with Various Deposits at $600^{\circ} \mathrm{C}$ and $700^{\circ} \mathrm{C}$

Corrosion weight losses of specimens caused by a mixture of $70 \% \quad \mathrm{~V}_{2} \mathrm{O}_{5}+30 \% \quad \mathrm{Na}_{2} \mathrm{SO}_{4}$ varied with temperature and test period, as shown in Fig. 8. As the mixture did not melt, weight losses were slight at $550^{\circ} \mathrm{C}$. Although the corrosion rate in the earlier test period at $575^{\circ} \mathrm{C}$ was very slow, it was accelerated with progressive corrosion.

The corrosion weight losses at $650^{\circ} \mathrm{C}$ was larger than those at $600^{\circ} \mathrm{C}$ in the earlier test period, but after 130 hours, weight losses at $650^{\circ} \mathrm{C}$ decreased at $600^{\circ} \mathrm{C}$ (Fig. 8). Corrosion weight losses after 200 hours increased as follows: $550^{\circ}<575^{\circ}<650^{\circ}$

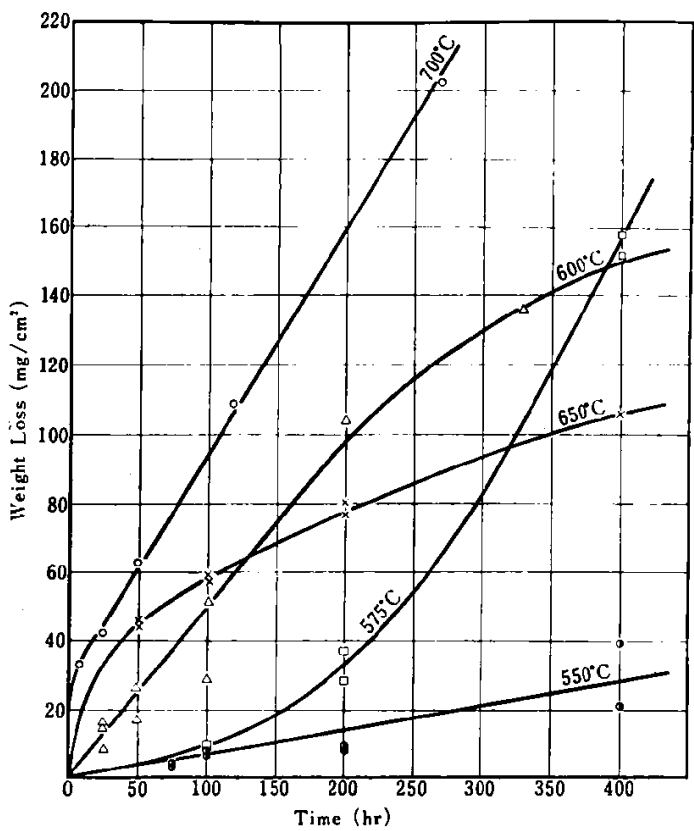

Fig. 8 Corrosion of SUS 27 Stainless Steel in 70\% $\mathrm{V}_{2} \mathrm{O}_{6}+30 \% \mathrm{Na}_{2} \mathrm{SO}_{4}$ mxiture at various Tempera tures

$<600^{\circ}<700^{\circ} \mathrm{C}$, as shown in Fig. $6(\mathrm{c})$.

It is considered that the corrosion mechanisms changed at those temperatures.

\section{Effect of Oxygen Concentration in Gases}

The corrosion tests described above were carried out in air. As of oxygen concentrations in combustion gases are only $1 / 10-1 / 20$ those in air, corrosion tests were carried out at various oxygen concentrations to determine the effect on corrosion.

As shown in Fig. 9, the corrosion weight losses caused by the $\mathrm{V}_{2} \mathrm{O}_{5}-\mathrm{Na}_{2} \mathrm{SO}_{4}$ mixtures at $700^{\circ} \mathrm{C}$ were constant at oxygen concentration above $2 \%$, but below $2 \%$ they decreased. Corrosion weight losses caused by the mixtures at $650^{\circ} \mathrm{C}$ increased proportionally with the oxygen concentration, and the weight losses by the superheater deposits at $700^{\circ} \mathrm{C}$ were only slightly affected by the oxygen concentrations.

From these results and the corrosion rate discussed in 4.4, it is believed that corrosion weight loss was similar at above $2 \%$ oxygen concentration when the weight loss increased linearly with the test period. However when it increased parabolically, weight loss increased linearly with increase of the concentration.

From the above results, it is conjectured that high temperature corrosion by fuel oil ash in a boiler will decrease with the low excess air firing. 


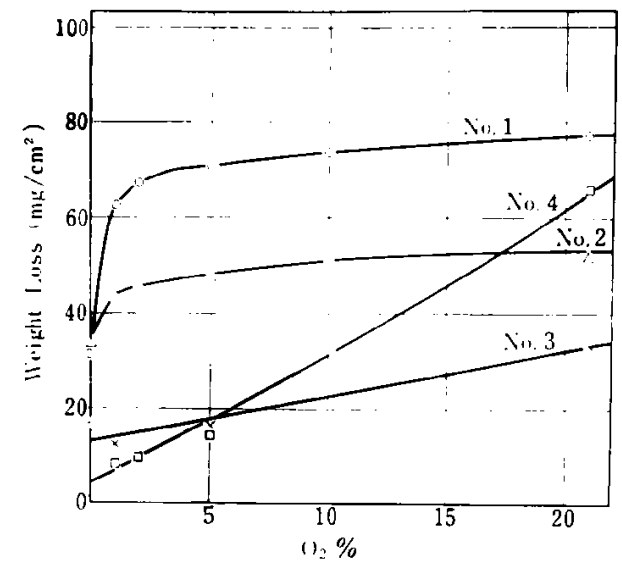

No. 1: $\mathrm{Y}_{2}()_{5}-\mathrm{Na}_{2} \mathrm{SO}_{4}(20 \%), 700^{\circ} \mathrm{C}, 24 \mathrm{hr}$

No. 2: $\mathrm{Y}_{2} \mathrm{O}_{5}-\mathrm{Na}_{2} \mathrm{SO}_{4}(30 \%), 700^{\circ} \mathrm{C}, 24 \mathrm{hr}$

No. 3: Power station $B$ secondary superheater depoist, $700^{\circ} \mathrm{C}, 24 \mathrm{hr}$

No. 4: $\mathrm{V}_{2} \mathrm{O}_{5}-\mathrm{Na}_{2} \mathrm{SO}_{4}\left(300_{0}\right), 650^{\circ} \mathrm{C}, 100 \mathrm{hr}$

Fig. 9 Effect of Oxygen Concentrations on Air Corrosion of SUS-27 Stainless Steel by Fuel Oil Ash and Synthetic Ash

\section{Conclusion}

From the analysis and fusing characteristics of the oil ash deposits taken from four boilers, the following results were obtained.

(1) The sum of $\mathrm{V}_{2} \mathrm{O}_{3}, \mathrm{Na}_{2} \mathrm{O}$ and $\mathrm{SO}_{3}$ in the ull ash deposits were $\mathbf{7 0 - 9 0 \%}$.

(2) Ratios of $\mathrm{V}_{2} \mathrm{O}_{5} / \mathrm{Na}_{2} \mathrm{O}$ and $\mathrm{SO}_{3} / \mathrm{Na}_{2} \mathrm{O}$ in the deposits were distributed around the straight lines represented as $\mathrm{Na}_{2} \mathrm{SO}_{4}+\mathrm{xV}_{2} \mathrm{O}_{5}+\mathrm{ySO}_{3}$.

(3) All of the deposits contained the same constituents, fusing at about $570^{\circ} \mathrm{C}$.

Corrosion tests with those deposits were carried out to find the relation between the corrosion weight losses and the deposit characteristics. The conclusions are as follows:

1) Corrosion weight losses by oil ash deposits increased with the increase of the molar ratio of $\mathrm{V}_{2} \mathrm{O}_{5} / \mathrm{Na}_{2} \mathrm{O}$ in the deposits.

2) Corrosion weight losses by the oil ash deposits taken from the higher temperature zones, secondary superheater and high temperature reheater, were less than those taken from lower temperature zones.

3) Corrosion weight losses by the deposits and $\mathrm{V}_{2} \mathrm{O}_{5}-\mathrm{Na}_{2} \mathrm{SO}_{4}$ mixtures occurred at above $570-$ $580 \mathrm{C}$

4) Corrosion weight losses at oxygen concentration above $2 \%$ were similar if the corrosion weight losses would increase linearly with the time. However, if the weight losses would increase parabolically with the time, they increased proportionally with the oxygen concentration.

\section{Acknowledgement}

The author wishes to express his sincere thanks to Dr. Ken-ichi Oda, Research Advisor of Central Research Institute of Electric Power Industry, for valuable advice and discussions in this study.

\section{References}

1) Cunningham, G.W., Brasunas, A., Corrosion, 12 $389 t-405 t$ (1956).

2) Monkman, F.C. Grant, N. J., ibid., 9, 460 (1953)

3) Foster, W.R., Leipold, M.H., Shevlin, T.S., ibid., 12, 539 t (1956).

4) Mcllroy, J.B., Holler, E.J., Lee, R.B., Trans ASME, 76. 31 (1954).

5) Young. W.E. Hershey, A.E., Hussey, C.E., ibid., 77. 985 (1955).

6) Lucas, (i., Weddle, MI., Preece, A. $J I S I, 179,342$ (1955).

7) Norris, R.S., Corrosion, 13, 123 (1957).

8) Jarvis, W.D., J. Inst. Fuel, 31, 480 (1958).

9) Niles, IV.D., Sanders, H.R., ASME paper 60-WA278.

10) Harris, G.T., Child, H.C., Kerri, J.A., JISI, 179, 241 (1955).

11) Fitzer, E., Schwab, J., Corrosion 12, 459 t (1956).

12) Wickert, K. Erdöl. u. Kohle, 1960, (9), 658.

13) Alexander, P.A., Marsden, R.A., Nelson-Allen, J.MI., Stewart, IV.A., J. Inst. Fuel, 37, 59 (1964).

14) Johnson, H.R., Littler, D.J., "Mechanism of Corrosion by Fuel Impurities", 534 (1963) Butterworth, London. 